\title{
ANALISIS TENTANG PENGUTIPAN SKRIPSI MAHASISWA SEBAGAI ANTISIPASI PLAGIARISME DI STKIP NIAS SELATAN
}

\section{ANALYSIS OF STUDENTS IN ANTICIPATION THESIS CITATIONS PLAGIARISM IN SOUTH NIAS STKIP}

\author{
AGUSTINUS DUHA, S.Pd., M.Pd. ${ }^{1)}$; BIMERDIN DAELY, S.Pd., M.Pd. ${ }^{2)}$ \\ Dosen Prodi Pendidikan Bahasa dan Sastra Indonesia STKIP Nias Selatan ${ }^{1)}$ \\ Dosen Prodi Pendidikan Bahasa dan Sastra Indonesia STKIP Nias Selatan ${ }^{2)}$ \\ Jl. Pramuka, Nari-Nari, Kel. Pasar Telukdalam, Kec. Telukdalam, Nias Selatan, Sumatera Utara \\ *Email : agustinusduha12@gmail.com \\ bimerdin.daely@ymail.com
}

\begin{abstract}
Abstrak. Seorang mahasiswa yang akan menyelesaikan tugas akademiknya, akan dihadapkan pada tugas akhir yang harus diselesaikannya yaitu menulis karya ilmiah (skripsi). Sehubungan dengan kegiatan menulis di atas maka mahasiswa dituntut untuk dapat menuangkan ide-idenya secara logis dan rasional. Dalam merangkai ide yang ilmiah maka harus mampu menggunakan bahasa sebagai medianya untuk mengaktualisasikan gagasannya tersebut. Ketika seorang mahasiswa tidak memiliki kemampuan pada aspek di atas maka akan muncul ide untuk mencari referen dari mana saja yang penting ada sehingga tidak terhindarkan dari tindakan menyimpang dalam mengutip pendapat orang lain dan menjadikanya sebagai pendapatnya atau melakukan tindakan plagiarisme. Setelah dilakukan analisis, permasalahan yang terdapat pada skripsi yang dijadikan sampel penelitian kurang lebih sama. Yang membedakannya adalah persentasenya. Misalnya skripsi a.n. Derisman Bawamenewi dengan Similarity Found: 33\%, skripsi Eldison dengan Similarity Found: 25\%, skripsi Ernimawati Gulo dengan Similarity Found: $21 \%$, skripsi Etika Halawa Similarity Found: 54\%, skripsi Gakhimi Wau Similarity Found: 27\%, skripsi Intan H. Laia Similarity Found: 23\%, skripsi Nur Kaidah Dachi Similarity Found: $30 \%$, skripsi Reminis Cere Hia Similarity Found: 43\%, skripsi Salua B. Gowasa Similarity Found: $20 \%$, skripsi Report Suci Hati Buulolo Similarity Found: 21\%, Sinjo Bu'ulolo Bab I-III Similarity Found: 60\% dan Bab 4-5 Similarity Found: 11\%, Wenihati Gaurifa Similarity Found Bab I: 7\%, Bab II: 80\%, Bab III: 14\%, Bab IV: 7\%, Bab V: 4\%, Yustina Novewati Bu'ulolo Bab I-III Similarity Found: 56\% dan Bab 4-5 Similarity Found: 14\%. Hendaknya mahasiswa secara aktif dan mandiri dalam mengembangkan wawasan, ide yang logis, dan pengetahuan serta berkontribusi positif melalui sumbangsih pemikiran dalam dunia pendidikan, sehingga tidak tergantung pada skripsi yang sudah dibuat sebelumnya; Hendaknya dalam penulisan skripsi mahasiswa memahami bagaimana merujuk dan mengutip sesuai dengan Panduan Penulisan Skripsi (PPS) yang dimiliki oleh STKIP Nias Selatan; Penelitian ini dapat dijadikan sebagai dasar atau pedoman penelitian yang hasilnya dapat disempurnakan maupun dikembangkan sesuai dengan dinamisasi perubahan paradigma pendidikan di Indonesia.
\end{abstract}

Kata Kunci: Pengutipan; skripsi; antisipasi plagiarisme.

Abstract. A student who will complete their academic assignments, will be faced with the task to be completed end of writing scientific papers (thesis). In connection with the above writing activities, students are required to be able to pour his ideas logically and rationally. In crafting the idea that scientific it must be able to use language as a medium to actualize the idea. When a student does not have the ability in the aspect above, it would appear the idea to find referents from which all that matters is that inevitably deviate from the action in citing the opinions of others and menjadikanya as his opinion or act of plagiarism. After analysis, the application of these thesis research sample approximately the same. What distinguishes it is the percentage. For example, the thesis an Derisman Bawamenewi with Similarity Found: 33\%, theses Eldison with Similarity Found: 25\%, theses Ernimawati Gulo with Similarity Found: 21\%, essay Ethics Halawa Similarity Found: 54\%, theses Gakhimi Wau Similarity Found: 27\%, essay Intan H. Laia Similarity Found: $23 \%$, theses Nur Rule Dachi Found Similarity: 30\%, theses Reminis Cere Hia Found Similarity: 43\%, theses Salua B. Gowasa Similarity Found: 20\%, Sacred Heart thesis Buulolo Report Similarity Found: $21 \%$, Sinjo Bu'ulolo Chapters I-III Similarity Found: $60 \%$ and Chapters 4-5 Similarity Found: 11\%, Wenihati Gaurifa Similarity Found Chapter I: 7\%, Chapter II: 80\%, Chapter III: 14\%, Chapter IV : 7\%, Chapter V: 4\%, YUSTINA Novewati Bu'ulolo Chapters I-III Similarity Found: $56 \%$ and Chapters 4-5 Similarity Found: $14 \%$. Students should actively and independently in developing insight, logical ideas, and knowledge and contribute positively through that ideas in education, so it is not dependent on the thesis that has been made before; Should be in the writing of the students understand how to refer to and quote according to Thesis Writing Guide (PPS), which is owned by South Nias STKIP; This study can be used as a basis or guidelines for research whose results can be refined and developed in accordance with the dynamic changes in paradigm of education in Indonesia.

Keywords: Citations; thesis; anticipation of plagiarism. 


\section{PENDAHULUAN}

Kehidupan akademik memiliki track record yang amat panjang sebagai lingkungan yang memiliki aturan tersendiri, bersifat independen, dan tidak memihak. IImu pengetahuanya dapat subur berkembang apabila karakteristik dasar tersebut dipertahankan. Untuk mempertahankan hal tersebut maka pengembangan ilmu pengetahuan dan kehidupana kademik secara umum memiliki etika dan aturan tertentuyang harus bebas dari kepentingan sesaat. Nilai-nilai etika dan moral selayaknya mendominasi kehidupan akademik. Akademisi harus mempunyai tambatan moral dan etika untuk membuat karakter mereka menjadi kuat. Akademisi yang tidak memiliki standar etika dan moral akademik yang tinggi dapat memanfaatkan lembaga pendidikan (tinggi) sebagai alat untuk manipulasi banyak hal termasuk tindakan plagiarisme dalam menulis karya ilmiah sebagai tugas akhir bagi mahasiswa.

Seorang mahasiswa yang akan menyelesaikan tugas akademiknya, akan dihadapkan pada tugas akhir yang harus diselesaikannya yaitu menulis karya ilmiah (skripsi). Sehubungan dengan kegiatan menulis di atas maka mahasiswa dituntut untuk dapat menuangkan ide-idenya secara logis dan rasional. Dalam merangkai ide yang ilmiah maka harus mampu menggunakan bahasa sebagai medianya untuk mengaktualisasikan gagasannya tersebut. Ketika seorang mahasiswa tidak memiliki kemampuan pada aspek di atas maka akan muncul ide untuk mencari referen dari mana saja yang penting ada sehingga tidak terhindarkan dari tindakan menyimpang dalam mengutip pendapat orang lain dan menjadikanya sebagai pendapatnya atau melakukan tindakan plagiarisme.

Kasus plagiarisme sedang marak di Indonesia beberapa tahun terakhir ini dibeberapa perguruan tinggi yang ada. Dalam KBBI, Plagiarisme ialah penjiplakan yang melanggar hak cipta, yaitu hak seseorang atas hasil penemuannya yang dilindungi oleh undang-undang. Plagiarisme tidak hanya dilakukan oleh pelajar tetapi juga mahasiswa; bahkan mahasiswa pascasarjana dan para pendidik perguruan tinggi di negara maju pun tidak terlepas dari plagiarisme.

Kemajuan dunia internet juga memiliki sisi negatif dan positif terhadap tindakan plagiarisme. Sisi negatif adalah kesempatan melakukan plagiarisme akan makin mudah dengan adanya akses terhadap jutaan artikel ilmiah. Sedangkan sisi positif adalah internet mampu menjadi jembatan untuk mengecek apakah artikel yang ada sama atau berbeda dengan artikel yang telah dipublikasikan orang lain.

Tindakan di atas tidak boleh dibiarkan dan perlu penanganan secara serius untuk antisipasi. Antisipasi adalah tindakan yang dilakukan untuk mencegah sebelum sesuatu terjadi. Di STKIP Nias Selatan setiap mahasiswa yang ingin menyelesaikan studinya wajib menulis karya ilmiah dan tidak terlepas pada tindakan untuk mengutip pendapat orang lain dan menjiplakannya sebagai pendapatnya dan pembaca percaya atas tindakannya itu. Agar tindakan ini tidak terus berlanjut maka perlu diberikan pemahaman kepada setiap mahasiswa tentang etika pengutipan pendapat orang lain dalam menulis karya ilmiah (skripsi).

Pada penelitian ini yang menjadi fokus penelitian adalah apa terdapat pengutipan langsung dan tidak langsung dalam karangan untuk skripsi mahasiswa program studi Pendidikan Bahasa dan Sastra Indonesia di STKIP Nias Selatan? apa tipe-tipe plagiarisme dalam karangan untuk skripsi mahasiswa program studi Pendidikan Bahasa dan Sastra Indonesia di STKIP Nias Selatan? dengan tujuan Untuk mendeskripsikan pengutipan langsung dan tidak langsung dalam karangan untuk skripsi mahasiswa program studi Pendidikan Bahasa dan Sastra Indonesia di STKIP Nias Selatan. Berdasarkan identifikasi masalah tersebut maka peneliti merumuskan judul penelitian "Analisis Tentang Pengutipan Skripsi Mahasiswa sebagai Antisipasi Plagiarisme di STKIP Nias Selatan".

\section{METODOLOGI PENELITIAN}

Penelitian ini mendeskripsikan pengutipan dalam karangan untuk skripsi mahasiswa sebagai antisipasi plagiarisme di STKIP Nias Selatan. Pendeskripsiannya meliputi: pengutipan langsung dan tidak langsung; plagiat berdasarkan aspek yang dicuri, berdasarkan sengaja atau tidak sengaja, berdasarkan proporsi atau prosentase yang dibajak, plagiat berdasarkan pola.

Populasi dalam penelitian ini adalah skripsi mahasiswa program studi Pendidikan Bahasa dan Sastra Indonesia STKIP Nias Selatan tahun pembuatan 2014 dan 2015 sebanyak 50 Skripsi.

Penelitian ini dilaksanakan di Perpustakaan STKIP Nias Selatan.

Alat pengumpulan data yang digunakan dalam penelitian ini adalah observasi dengan teknik membaca saksama. Peneliti membaca saksama secara teliti sehingga pengutipan dan plagiat yang terdapat pada skripsi yang ditulis oleh mahasiswa Program Studi Pendidikan Bahasa dan Sastra Indonesia STKIP Nias Selatan tidak luput dari pengamatan/perhatian peneliti.

Untuk mengetahui hambatan mahasiswa dalam penyusunan (penulisan) skripsi, maka peneliti mengajukan angket dan wawancara kepada beberapa orang penulis tugas akhir yang sudah menjadi alumni.

Teknik analisis data yang digunakan dalam penelitian ini adalah teknik analisis data induktif, yang merupakan penarikan kesimpulan dari fakta-fakta yang khusus, untuk kemudian ditarik kesimpulan secara umum (generalisasi). Beberapa langkah dalam analisis data tersebut antara lain: 


\section{a. Pengumpulan Data}

Pengumpulan data adalah suatu usaha untuk menghimpun informasi yang berhubungan dengan penelitian. Pengumpulan data dilakukan secara serentak dengan komponen yang lain selama kegiatan penelitian berlangsung dengan menggunakan satu atau lebih teknik pengumpulan data dalam metode kualitatif. Pada waktu data mulai terkumpul, saat itu juga sudah dimulai untuk memaknai dari setiap data yang ada, selanjutnya memberikan penjelasan mudah dipahami dan ditafsirkan untuk menjawab dari setiap pertanyaan yang muncul.

\section{b. Reduksi Data}

Reduksi data seringkali tampak pada saat sebelum memutuskan kerangka konseptual wilayah penelitian, permasalahan penelitian dan pengumpulan data mana yang dipilihnya. Reduksi data berlangsung dan berlanjut terus sesudah penelitian laporan, sampai laporan akhir lengkap tersusun. Sebagai bagian dari analisis, maka proses menajamkan, menggolongkan, mengarahkan, membuang yang tidak perlu dan mengorganisasikan data merupakan hal yang amat penting dilakukan selama penelitian dilaksanakan.

\section{c. Penyajian Data}

Data disajikan dalam bentuk narasi berupa informasi mengenai pengutipan dan plagiat pada skripsi mahasiswa program studi Pendidikan Bahasa dan Sastra Indonesia STKIP Nias Selatan, yaitu mencakup pengetahuan dan pemahaman mahasiswa mengenai pengutipan, plagiat, tipe-tipe plagiat, dan faktor penyebab plagiat.

\section{d. Menarik Kesimpulan atau Verifikasi}

Dari permulaan pengolahan data, peneliti mulai mencari makna dari data-data yang telah terkumpul. Selanjutnya peneliti mencari arti dan penjelasannya kemudian menyusun pada hubungan tertentu yang mudah dipahami dan ditafsirkan. Data tersebut dihubungkan dan dibandingkan antara satu dengan yang lainnya sehingga mudah ditarik kesimpulannya sebagai jawaban atas setiap permasalahan yang ada. Data yang telah diproses dengan langkah-langkah seperti di atas kemudian ditarik suatu kesimpulan dengan metode induktif yang berangkat dari hal-hal yang khusus untuk memperoleh kesimpulan umum secara objektif. Penarikan kesimpulan dalam penelitian ini dengan melihat kembali data yang direduksi, diunitisasi dan kategorisasi serta di-display sehingga kesimpulan yang diambil tidak menyimpang dari permasalahan penelitian sesuai dengan fakta di lapangan.

\section{PEMBAHASAN HASIL PENELITIAN}

Metode yang digunakan dalam penelitian ini adalah metode deskripstif kualitatif. Sumber data dalam penelitian ini adalah skripsi mahasiswa program studi Pendidikan Bahasa dan Sastra Indonesia STKIP Nias Selatan tahun pembuatan 2014 dan 2015. Sampel penelitian ini berjumlah 19 skripsi. dari ke-19 skripsi yang dianalisis, hasilnya adalah sebagai berikut.

\section{1). Auguso Buulolo}

Bab I-III Similarity Found: 53\%

Bab IV-V Similarity Found: 18\%

Date: Kamis, Juli 18, 2019 Statistics: 1165 words Plagiarized/6565 Total words

Pada BAB I, bagian latar belakang masalah terdapat kutipan tentang pengertian berbicara tanpa menyertakan sumber kutipan. Selanjutnya, mengutip pengertian dialog dari KBBI (2003) padahal terindikasi hal tersebut diambil dari sumber lain/tidak asli diambil dari KBBI. Beberapa hasil observasi awal juga diambil dari sumber lain, tidak semua berasal dari hasil observasi peneliti. Hal yang berikut adalah di bagian rumusan masalah, yaitu terdapat plagiat dengan mengutip dari sumber yang tidak jelas tentang model mind mapping. Hal yang sama terjadi pada bagian rumusan masalah. Definisi istilah juga diambil dari sumber lain yang belum jelas.

BAB II, pada bagian teori terdapat banyak kutipan dan pernyataan yang diambil tidak dari sumber aslinya, misalnya penulis skripsi mengambil pengertian berbicara dari pendapat Tarigan (1987:15), Mugrave (1954:3-4), Brooks dalam Tarigan (1983:12), Oktariana (tahun dan halaman belum jelas), Novia (2002 tanpa halaman), padahal terindikasi bahwa penulis skripsi mengambil pendapat di atas dari sumber lain. Demikian halnya dengan kesimpulan pengertian berbicara juga diambil dari sumber lain. Beberapa konsep tentang hakikat berbicara juga diambil dari sumber yang belum jelas dan terindikasi plagiat, seperti teori prinsip berbicara, faktor yang perlu diperhatikan dalam kegiatan berbicara, dan tujuan berbicara.

Selain itu, konsep dasar tentang dialog dan dialog interaktif juga terindikasi plagiat. Dalam hal ini, penulis mengutip KBBI (tanpa tahun dan halaman), Admin (2004 tanpa halaman), Hardjana (2011:52), Hardjana (2007:104).

Pengutipan teori Model Pembelajaran Mind Mapping juga tidak luput dari aksi plagiat. Penulis mengutip pendapat Buzan, Tony (2012:12; 2009:12,16,18; 2008:4; 1970-an), Deporter dan Hernaki (2011:152), Wycoff (2013:53), Sugiarto, Iwan (2004 tanpa halaman) dan beberapa pernyataan lain yang berkaitan dengan konsep mind mapping terindikasi plagiat atau diambil dari karya orang lain tanpa menyertakan identitas lengkap.

Pada BAB III, terdapat kutipan pengertian tindakan kelas yang diambil dari pendapat Arikunto (2006:3). Beberapa kalimat yang terindikasi plagiat lagi di antaranya fungsi PTK, kalimat objek penelitian, beberapa kalimat pada langkah pelaksanaan PTK, kalimat-kalimat pada lembar wawancara, 
Pada BAB IV, jika dilihat dari persentase, maka $18 \%$ similarity found. Pada bab ini, penulis mengcopy paste beberapa kalimat, misalnya setting penelitian, subjek penelitian, dan beberapa kalimat yang lain. Deksipsi tindakan, observasi, refleksi, juga sebagian di-copy dari sumber lain. Beberapa kalimat dari hasil penelitian juga diambil dari sumber lain, tetapi angka-angka hasil penelitian tidak terindikasi plagiat.

\section{Adilia Ndruru}

Bab I-V Similarity Found: $22 \%$

Date: Rabu, Juli 17, 2019, Statistics: 2621 words Plagiarized / 12027 Total words

Bab I pada bagian latar belakang terdapat kalimat yang terindikasi plagiat. Kalimat "menulis merupakan salah satu", menulis "sangat penting bagi pendidikan karena", dan beberapa kalimat lain yang terdapat dalam latar belakang masalah. Selain itu, penulis juga mengutip pendapat Morsey dalam Tarigan (1986:4) tentang pengertian menulis. Nah, yang berikut adalah mengutip kalimat dari laporan penelitian orang lain tentang masalah penelitian, kelas tempat pelaksanaan penelitian, hanya diubah lokasinya, dan kalimat strategi yang digunakan juga terindikasi plagiat, yakni stategi pembelajaran The Power of Two.

Pada bagian rumusan masalah, tujuan penelitian, manfaat penelitian, dan definisi istilah juga terdapat kalimat yang di-copy dari skripsi orang lain.

Bab II Kajian Pustaka

Terdapat kutipan pada konsep dasar menulis, misalnya pengertian menulis dikutip dari Tarigan (2008:22), Semi (2007:14), KBBI (1995:1079), tujuan menulis juga dikutip dari sumber yang tidak jelas, dan mengutip pendapat Tarigan (2008:24). Tahap menulis juga dikutip dari pendapat Semi (2007:46) dan kutipan tersebut tidak diambil langsung dari sumber asli. Kesimpulan dari proses menulis juga terindikasi plagiat. Pendapat Akhadiah, dkk (1989:1) tentang manfaat menulis terindikasi plagiat. Kalimat-kalimat yang membahas tentang pengertian berita yang dikutip dari KBBI (1995:123), Djuraid (2006:11), Mitchel V. Charnley (tanpa tahun dan halaman), Doug Newsom dan James A. Wollert (tanpa tahun dan halaman), Assegaf (tanpa tahun dan halaman), dan J.B. Wahyudi (tanpa tahun dan halaman). Selanjutnya, penjelasan tentang jenis-jenis berita, unsur-unsur berita, syarat sumber berita, bagian-bagian berita, teknik menulis berita, penilaian menulis berita juga sebagian diambil dari sumber yang tidak jelas. Selanjutnya, konsep dasar strategi pembelajaran The Power of Two juga terindikasi plagiat. Penulis skripsi mengemukakan pengertian, tujuan, langkah-langkah pelaksanaan, kelebihan dan kekurangan strategi pembelajaran tersebut dengan mengutip pendapat Zain (2008:52), Mafatih (sumber dari http://media.diknas.go-id), Hamurni (2012:160). Simpulan tentang pengertian strategi pembelajaran di atas juga diambil dari hasil tulisan orang lain.

Di dalam Bab III Metodologi Penelitian terdapat beberapa kutipan dan kalimat yang belum jelas sumber atau dikutip dari pendapat ahli dari hasil tulisan orang lain. Hal tersebut dapat dilihat dari pengertian dan dasar pelaksanaan PTK diambil dari pendapat Sanjaya (2009:26), Depdiknas (2003:8). Kelas dan jenjang pendidikan juga terindikasi diambil/di-copy dari hasil tulisan orang lain. Yang dibedakan adalah lokasi penelitiannya.

Beberapa kalimat yang terdapat pada uraian tahap pelaksanaan PTK juga di-copy dari tulisan orang lain. Pada bagian instrumen penelitian juga diindikasikan beberapa kalimat diambil dari karya orang lain, di antaranya kalimat "Instrumen yang digunakan dalam penelitian ini", "... yang digunakan dalam penelitian ini", Lembaran observasi digunakan untuk.... penerapan strategi pembelajaran The Power of Two", "...digunakan untuk mengertahui apakah langkah-langkah ... saat melakukan pembelajaran di kelas sesuai dengan langkah-langkah penerapan Strategi pembelajaran The Power of Two", dan beberapa kalimat lain yang dapat dilihat pada lampiran penelitian ini. Demikian halnya pada analisis data. Ada kalimat yang di-copy dari tulisan orang lain.

Pada Bab IV Temuan Penelitian dan Pembahasan juga terdapat kalimat-kalimat yang tidak murni ditulis oleh penulis skripsi, di antaranya kalimat "penelitian tindakan kelas", "penelitian ini mengikuti alur", pembelajaran menulis teks berita dan....", "strategi pembelajaran the power of two", "menulis teks berita dan....", "...selama kegiatan belajar mengajar berlangsung", "kemampuan siswa menulis teks berita melalui strategi pembelajaran the power of two di kelas VIII SMP Negeri 1 ... Pembelajaran pada siklus I", dan beberapa kalimat yang mendeskripsikan tahap pelaksanaan PTK yang sudah dilakukan. Beberapa kalimat yang menguraikan hasil penelitian juga diambil dari hasil tulisan orang lain, hanya saja hasil atau angka murni dibuat sendiri oleh penulis skripsi.

\section{Adilina Ndruru}

Bab I-V Similarity Found: 17\%

Date: Rabu, Juli 17, 2019, Statistics: 2264 words Plagiarized / 13031 Total words

Bab I Pendahuluan

Ada beberapa hal yang terindikasi plagiat pada bagian ini, yaitu pada bagian latar belakang masalah terdapat beberapa kalimat yang tidak murni ditulis oleh penyusun skripsi, seperti kalimat "menulis merupakan salah satu...", "... dibaca dan dipahami oleh orang ...., "...menyimak, berbicara dan membaca. Kemampuan menulis menghendaki penguasaan berbagai unsur kebahasaan dan dluar bahasa itu sendiri yang akan menjadi isi ....", "...menulis biasanya dikaitkan dengan pembelajaran mengarang. Latihan menulis dalam pengajaran ... Bahasa Indonesia dapat membiasakan siswa untuk menerapkan pengetahuan kebahasaan, seperti tata bahasa, kosa kata, gaya bahasa, ejaan, dan sebagainya", "Teknik Discussion Starter Story ...", 
“...berkaitan dengan latar belakang....", "...menyusun cerita tersebut dalam bentuk ....". pada batasan penelitian juga terdapat kalimat yang

diambil dari hasil tulisan orang lain, misalnya "melakukan penelitian dengan judul ...", Teknik Discussion Starter Story ...", “...kemampuan menulis paragraf eksposisi ... teknik Discussion Starter Story". Pada bagian rumusan masalah terdapat kalimat "dalam penelitian ini pada ... teknik Discussion Starter Story ... kemampuan menulis paragraf eksposisi siswa kelas X ....", "teknik Discussion Starter Story ....", "teknik Discussion Starter Story ....". pada bagian tujuan penelitian juga terdapat kalimat "...rumusan masalah di atas, maka tujuan penelitian ini adalah sebagai berikut.", "...peningkatan kemampuan menulis paragraf eksposisi ... teknik Discussion Starter Story ....", “...penelitian ini dapat menjadi ... secara aktif dalam proses pembelajaran ....". pada bagian manfaat penelitian juga terdapat kalimat yang terindikasi plagiat.

Bab II Kajian Pustaka

Pada bagian ini terdapat beberapa kalimat dan kutipan yang masuk kategori plagiat, seperti pada konsep dasar menulis. Penulis skripsi mengemukakan pengertian menulis dan simpulannya tanpa jelas sumbernya atau mengambil simpulan orang lain. Penulis mengutip pendapat Kartono (2009:17), Batrasius (dikutip dari http://batrasiaku.), Tarigan (2005:21), Tarigan dan Laoli (2010:12), pendapat Gultom (2012:5-6), Syarif (2009:6) tentang tujuan menulis, konsep tentang manfaat menulis juga tidak jelas sumbernya. Teori proses menulis juga dikutip dari Mawabah (2011:66). Teori paragraf juga diambil dari beberapa pendapat ahli, tetapi yang terindikasi plagiat adalah kutipan dari pendapat Rismawati (2011:59). Uraian tentang fungsi syarat paragraf juga terindikasi plagiat. Pengertian paragraf eksposisi juga ada belum jelas sumbernya dan ada juga yang sumbernya jelas, misalnya pendapat Juhara (2009:67), Syarif, dkk (2009:7), Indawti (2008:42). Ciri-ciri paragraf eksposisi juga terindikasi banyak kalimat yang plagiat. Penulis skripsi mengutip pendapat Indawati (2008:42-43), Kosasih (2003:48).

Teori tentang Teknik Discussion Starter Story juga terindikasi plagiat, hanya tidak utuh. Dalam arti, penulis skripsi mengedit beberapa kalimat sesuai kebutuhannya.

Bab III Metodologi Penelitian

Pada bagian ini terdapat beberapa kalimat yang terindikasi tidak murni tulisan penulis skripsi, misalnya “... dengan penelitian tindakan kelas...", "tindakan kelas merupakan penelitian... guru dapat mengorganisasikan kondisi praktek pembelajaran....". pendapat Arikunto (2006:3) juga tidak diambil dari sumber asli. Beberapa kalimat pada subjek penelitian juga terindikasi diambil dari tulisan orang lain. Waktu dan lamanya penelitian juga diambil dari tulisan orang lain, tetapi sudah diedit. Tahap pelaksanaan kegiatan penelitian tindakan kelas, teknik analisis data, juga diambil sebagian dari tulisan orang lain.

Bab IV Temuan Penelitian dan Pembahasan

Pada bagian ini terdapat beberapa bagian kalimat yang terindikasi plagiat. Pada bagian deskripsi pelaksanaan penelitian, baik pada siklus I, maupun siklus II terdapat bagian-bagian kalimat yang tidak asli dari tulisan penulis skripsi. pada deksipsi pembahasan hasil penelitian terdapat juga beberapa bagian kalimat yang tidak murni ditulis oleh penulis skripsi.

\section{Afrianus Baene}

Similarity Found: $32 \%$

Date: Kamis, Juli 18, 2019, Statistics: 3539 words Plagiarized / 11057 Total words

Bab I Pendahuluan

Pada bagian latar belakang, hampir semua paragraf terdapat kalimat yang diambil dari sumber tidak jelas atau hasil tulisan orang lain. Demikian juga pada bagian batasan masalah, rumusan masalah, tujuan penelitian, manfaat penelitian, dan definisi istilah.

Bab II Kajian Pustaka

Kalimat atau kutipan yang terdapat pada bab ini sebagian diambil dari tulisan orang lain, misalnya tentang pengertian belajar dikutip dari pendapat Slameto (2010:2), Komalasari (2010:2), pengertian pembelajaran dikutip dari Rusman (2012:134), Komalasari (2010:3). Pengertian berbicara dikutip dari Tarigan (2008:16), Haryadi dan Zamzani (2000:72), Santosa (2006:34). Tujuan berbicara dikutip dari pendapat Tim Intersolusi (2006:84), Keraf (2001:320). Bentuk-bentuk keterampilan berbicara dikutip dari Tarigan (2008:24-25), Hartono (2005:30). Pada teori model pembelajaran kooperatif dikutip dari pendapat Davidson dan Warsham (Isjoni 2014: 29), Sanjaya (2006:242), Slavin (Rusman, 2013:205). Ciri-ciri, karakteristik, tujuan, langkah-langkah model pembelajaran kooperatif dikutip dari pendapat Riyanto (2010:266), Rusman (2013:207), Hamruni (2011:127), Iskandar (2009:127). Beberapa bagian kalimat yang menguraikan kelebihan dan kelemahan model pembelajaran kooperatif juga diindikasikan plagiat.

Pada bagian teori Pembelajaran Snowball Throwing juga banyak terindikasi kalimat-kalimat yang tidak murni dari tulisan penyusun skripsi.

Bab III Metodologi Penelitian

Bagian ini juga terindikasi plagiat. Mulai dari pengutipan pendapat Kunandar (2012:46) tentang pengertian PTK, kalimat yang terdapat pada bagian objek penelitian juga diambil dari tulisan orang lain. Tahap pelaksanaan PTK juga diambil dari tulisan orang lain sebagian. Beberapa rumus juga diambil dari tulisan orang lain. 
Bab IV Temuan Penelitian dan Pembahasan

Pada bagian ini ada beberapa bagian kalimat yang masuk kategori plagiat, seperti pada bagian setting penelitian terdapat bagian-bagian kalimat yang terdeteksi tulisan orang lain. Paparan pelaksanaan PTK juga terindikasi plagiat karena beberapa bagian kalimat tidak murni tulisan penulis skripsi.

Bab V Penutup

Bagian ini juga tidak luput dari kegiatan plagiat. Beberapa kalimat di dalamnya terindikasi diambil dari tulisan orang lain.

\section{Agustina Laia}

Similarity Found: $23 \%$

Date: Kamis, Juli 04, 2019, Statistics: 5647 words Plagiarized / 24786 Total words

\section{Bab I Pendahuluan}

Pada bagian ini terdapat kalimat yang terindikasi diambil atau di-copy dari hasil tulisan orang. Penulis skripsi ini mengutip beberapa pendapat terkait dengan pengertian membaca pada latar belakang masalah, yakni pendapat Tampubolon (1987:5), Hardjasudjana (1997:61), Ginting (2005:2), nama sekolah tempat penelitian juga terindikasi di-copy dari tulisan orang lain. Pendapat Zuhairini, dkk (2000:106), pendapat David dalam Ramlan (1993:91). Konsep tentang penilaian berbasis kelas juga sebagian diambil dari tulisan orang lain. Sebagian alasan penelitian juga terindikasi plagiat. Hal itu dapat dilihat pada kalimat yang terindikasi copy paste, seperti "... ada yang lambat, dan masih mempunyai kebiasaan buruk dalam membaca cepat. Hal ini disebabkan oleh kurangnya minat siswa dalam membaca cepat ....", "isi bacaan dengan membaca cepat 250 KPM. ... siswa terhadap mata pelajaran bahasa Indonesia masih kurang. Hal ini dapat dilihat dari ... kurang menguasai penggunaan bahasa Indonesia yang baik dan benar". Judul penelitian juga terindikasi plagiat, dapat dilihat pada bagian kalimat berikut, "“... Meningkatkan Keterampilan Membaca Cepat 250 KPM dengan Menggunakan Metode ... SMP Negeri 3 Lolomatua”. Pada bagian batasan masalah juga demikian, kalimat “... masalah dalam penelitian ini ... meningkatkan keterampilan membaca cepat 250 KPM ... upaya meningkatkan keterampilan membaca cepat $250 \mathrm{KPM}$ dengan menggunakan metode ", kalimat pada tujuan penelitian " ... meningkatkan keterampilan membaca cepat 250 KPM ...", “... upaya meningkatkan keterampilan membaca cepat 250 KPM dengan menggunakan metode ....". tulisan pada manfaat penelitian "Hasil penelitian ini diharapkan dapat ... meningkatkan minat dan motivasi belajar dalam membaca cepat", " ... dapat dijadikan sebagai bahan pertimbangan ....", "pembelajaran Latihan berjenjang dan .... di masa yang akan dating", " ... di SMP Negeri 3 Lolomatua", "dapat dijadikan sebagai bahan ... masa yang akan dating". Pada bagian definisi istilah terdapat kalimat "Membaca adalah proses yang dilakukan pembaca untuk memperoleh pesan yang hendak disampaikan penulis melalui media kata-kata atau bahasa tulis", “.... cepat adalah membaca dengan kecepatan tinggi, hampir keseluruhan materi dibaca dalam waktu tertentu yang disertai dengan pemahaman isi ....", "Materi dalam hal ini adalah jumlah kata yang terkandung dalam, ... memahami materi bacaan memerlukan waktu. Waktu yang dipergunakan dalam membaca cepat adalah satuan waktu ... artinya, setelah selesai membaca sekurangkurangnya pembaca menguasai isi bacaan ....", "... untuk memperoleh suatu ketangkasan atau keterampilan ....". Bab II Kajian Pustaka

Bagian ini terindikasi juga dalam kategori plagiat. Kutipan dan kalimat diambil dari tulisan orang lain. Hal itu dapat dibuktikan pada kalimat berkut ini. Kalimat "BAB II KAJIAN PUSTAKA", "Membaca adalah suatu proses yang dilakukan oleh pembaca untuk memperoleh pesan yang hendak disampaikan oleh penulis melalui media katakata ....", "proses yang menuntut agar kelompok kata merupakan suatu kesatuan akan terlihat dalam suatu pandangan sekilas dan agar makna kata-kata secara individual akan dapat diketahui. Kalau hal ini tidak ... maka pesan yang tersurat dan tersirat tidak akan tertangkap ... proses membaca itu tidak terlaksana dengan baik Hodgson, dalam Tarigan (1987:7).

Kalimat yang mambahas tentang membaca dari segi linguistik juga diambil dari tulisan orang lain. Kalimat tersebut dimulai dari "... adalah suatu proses penyandian kembali dan pembacaan sandi (a recording and decoding process), berlainan dengan berbicara dan menulis yang justru melibatkan penyandian (encoding). Sebuah aspek pembacaan sandi (decoding) adalah menghubungkan kata-kata tulis (written word) dengan makna bahasa lisan (oral language meaning) yang mencakup pengubahan tulisan/cetakan menjadi bunyi yang bermakna (Anderson dalam Tarigan, 1972:209-210). Pendapat Soedarso (2004:4), Nurhadi (1987:13) juga demikian. Terindikasi plagiat. Simpulan dari membaca juga mengalami hal yang sama. Manfaat membaca, diawali dengan pendapat yang tidak jelas sumber. Pendapat Emerson dalam Suyatmi (1984:9) dan Suryatmi (1984:89) dikutip oleh penulis untuk teori manfaat membaca. Pendapat Anderson dalam Tarigan (1987:9-10) tentang tujuan membaca juga terindikasi plagiat. Pendapat Nurhadi (2004:11), Tarigan (2005:13). Konsep dasar faktor-faktor yang memengaruhi membaca dikutip dari sumber tidak jelas dan dari pendapat ahli. Dari pendapat ahli terdapat nama Lamb dan Arnol Rahim Farida (2007:6)

Teori Membaca Cepat cikutip dari beberapa pendapat ahli, yaitu pendapat Hernowo (2003:9), Soedarso dalam buku Speed Reading (2002:18), Harjasujana (1996:164), Nurhadi (2005:5), Tampubolon (1990:7). Pendapat T. Aritonang (2006:10) tentang waktu membaca cepat juga dikutip dari tulisan orang lain. Kalimat tersebut, yakni "Waktu yang dipergunakan dalam membaca cepat adalah satuan waktu, 
yaitu menit .... artinya, setelah selesai membaca sekurang-kurangnya pembaca menguasai isi bacaan ...." simpulan pendapat ahli di atas juga diambil dari tulisan orang lain, yakni "... di atas dapat disimpulkan bahwa membaca cepat adalah proses membaca bacaan untuk memahami isi bacaan dengan cepat. Membaca cepat memberi kesempatan untuk membaca secara lebih luas, ... bagian bacaan yang sudah sangat dikenal atau .... Perhatian dapat difokuskan pada bagian-bagian yang baru atau bagian-bagian yang belum dikuasai.

Teori tujuan dan manfaat membaca cepat diambil penulis skripsi dari beberapa sumber, yaitu dari sumber yang belum jelas dan pendapat orang lain. Dari sumber yang belum dapat dilihat dari kalimat berikut: "bisa memperoleh pengetahuan yang luas tentang apa yang dibacanya sesuai dengan sifat bacaan yang tidak memerlukan....". Dari pendapat ahli adalah pendapat Albert dalam Harras (1997:25), dan Depdikbud (2005:7). Simpulan juga demikian. Kalimat "... tujuan dan manfaat membaca cepat adalah agar dalam waktu yang relatif singkat kita mampu mendapatkan hasil dan memahami bacaan sebanyak-banyaknya. Mengapa membaca cepat begitu penting? Hampir seluruh informasi yang kita dapatkan dari buku-buku, koran, majalah, tabloid, bahkan media internet seperti media online menyajikan informasi dalam bentuk teks bacaan.

Teori pola membaca cepat diambil dari pendapat Harjasudjana (1988:76). Kalimat yang terindikasi plagiat adalah "pembaca harus meluncurkan pandangannya dengan cepat sekali dari ujung kiri sampai ujung kanan setiap baris. Waktu pandangan bergerak kanan ke kiri, kecepatannya harus sekilat sebab pada saat itu tidak ada yang perlu diperhatikan, dan supaya hubungan baris yang satu dengan baris lainnya lebih erat .... mulai membaca dari halaman ....", pola membaca juga tidak luput dari kegiatan plagiat. Demikian halnya dengan teori hambatanhambatan membaca cepat juga mengalami hal yang sama. Kalimat "Orang yang tidak mendapat bimbingan, latihan khusus membaca cepat lelah dalam membaca karena lamban membaca, tidak ada gairah, merasa bosan, tidak tahan membaca buku dan terlalu lama untuk bisa menyelesaikan buku yang tipis sekalipun. Pada bagian ini, penulis skripsi mengutip pendapat Soedarso (2002:8) tentang alasan seorang pembaca melakukan regresi adalah sebagai berikut: Pembaca merasa kurang yakin dalam memahami tulisan yang dibacanya, pembaca merasa ada kesalahan cetak pada tulisan yang dibacanya kemudian mempertanyakan hal tersebut dalam hati Pembaca merasa ada kesalahan ejaan Ada kata sulit atau baru Pembaca terpaku pada detail Pembaca salah persepsi misalnya bertanya angka-angka baru dibacanya 266 atau 367 Pembaca merasa ada sesuatu yang tertinggal. Pendapat Redway dalam Wahyuningsih (2000:15) dengan berlatih "terus dan kecepatan membaca meningkat, maka usaha mencegah regresi ini akan lebih mudah lagi. Kecepatan akan memaksa si pembaca untuk berkonsentrasi lagi. Hasilnya akan lebih meningkat pemahaman secara keseluruhan dan akan mendorong pembaca untuk lebih siap mengantisipasi....", "Subvokalisasi atau melafalkan dalam batin atau pikiran kata-kata yang dibaca dilakukan oleh pemabaca yang kecepatannya lebih tinggi. Subvokalisasi juga menghambat karena kita menjadi lebih memperhatikan bagaimana melafalkan secara benar dari pada berusaha memahami ide yang dikandung dalam kata-kata yang kita baca itu Soedarso (2002:8)". "Wiryodijoyo dan Wahyuningsih (2000:13) mengungkapkan bahwa subvokalisasi ini merupakan pengaruh kebiasaan dalam pengajaran membaca di sekolah dasar, yaitu: mengeja kata-kata menjadi suku kata, kata menjadi huruf, dan mengucapkan berulang-ulang hal yang dianggap penting oleh guru. Untuk menghilangkan cara membaca dengan menghafalkan dalam hati hal yang kita ...". Soedarso (2002:9) "Namun ada cara lain untuk memperkecil akibat buruk dari subvokalisasi, yaitu dengan cara melebarkan jangkauan mata sehingga satu fiksasi (pandangan mata) dapat menangkap beberapa kata sekaligus dan langsung menyerap idenya. Cara ini lebih baik dari pada melafalkannya. Ketiadaan perhatian hampir sama dengan ketidaksiapaan mental.

Simpulan teori membaca di atas juga dikutip dari sumber yang tidak jelas. Kalimat “... di atas, dapat disimpulkan bahwa hambatan-hambatan dalam membaca cepat adalah vokalisasi, gerakan bibir, gerakan kepala, menunjuk dengan jari, regresi, subvokalisasi, ketiadaan perhatian dan kurang motivasi ...." teori Teknik Membaca Cepat dikutip dari pendapat Nurhadi, (1987:114). Teori langlah-langkah yang perlu ditempuh dalam membaca skimming dikutip dari pendapat Nurhadi (2005:120). Bacalah dengan kecepatan normal, dan pahami dengan baik apa yang anda cari itu. Membaca Skimming adalah membaca dengan cepat untuk mengetahui isi umum atau bagian suatu bacaan Rahim, (2007:52). Soedarso (2006:88), mendefinisikan teknik membaca skimming. Pendapat Nurhadi (2005:115) juga dikutip. Teori membaca skanning dikutip dari Soedarso (2006:89), Mikuley \& Jeffries, dalam Rahim, (2007:52) juga diambil dari tulisan orang lain. Simpulan membaca skimming dan membaca scanning juga terindikasi dari tulisan orang lain diambil oleh penulis skripsi. kalimat Dari beberapa pendapat di atas dapat disimpulkan bahwa ... adalah membaca dengan cepat untuk mengetahui isi umum atau bagian suatu bacaan. Membaca skimming dibutuhkan untuk mengetahui sudut pandang penulis tentang sesuatu, menemukan pola organisasi paragraf dan menemukan gagasan umum dengan cepat sedangkan teknik membaca skanning adalah teknik untuk menemukan informasi dari bacaan secara cepat.

Teori hal-hal yang perlu diperhatikan dalam membaca cepat dikutip dari Tarigan (2008:36). Kalimat lain yang terindikasi kalimat "Metode pembelajaran merupakan cara melakukan atau menyajikan, menguraikan, memberi contoh, dan memberi latihan isi pelajaran kepada siswa untuk mencapai tujuan tertentu. Dapat dikatakan pula bahwa metode pembelajaran merupakan bagian dari strategi instruksional. Strategi pembelajaran merupakan sebagai perencanaan yang berisi tentang rangkaian kegiatan yang didesain untuk mencapai tujuan pendidikan tertentu. 
Penulis skripsi juga mengutip pendapat Nana Sudjana (2005:76), M. Sobri Sutikno (2009:88) Gerlach dan Elly (1980:14), Roestiyah (2001:125), Zuhairini, dkk (2000:106) tentang metode pembelajaran. Pendapat David dalam Ramlan (1993:91) yang dikutip penulis juga termasuk plagiat. Kalimat "Latihan berjenjang adalah cara pembelajaran untuk melatih keterampilan siswa dalam mempelajari sesuatu yang dianggap sukar secara bertahap". Kalimat simpulan juga begitu. Pasaribu dan B. Simandjuntak (2001:112), dan Roestiyah (2001:125126) juga dikutip dari sumber lain, yakni "Tujuan dan Manfaat Metode Latihan Berjenjang Tujuan Metode Latihan Berjenjang Tujuan metode latihan berjenjang adalah untuk memperoleh suatu ketangkasan atau keterampilan tentang sesuatu yang dipelajari anak dengan melakukannya secara praktis pengetahuan yang dipelajari anak itu dan siap dipergunakan bila sewaktu-waktu diperlukan". "Metode latihan berjenjang bertujuan untuk agar siswa: Memiliki keterampilan motoris/gerak, seperti menghafal kata-kata, menulis, mempergunakan alat atau membuat suatu benda; melaksanakan dalam olahraga Mengembangkan kecakapan intelek, seperti mengalikan, membagi, menjumlahkan, mengurangi, menarik akar dalam hitungan mencongak, mengenal benda/bentuk dalam pelajaran bahasa Indonesia, tanda baca dan sebagainya". Pendapat E.Kosasih, (2010:73) juga diambil dari tulisan orang lain. Kalimat "E.Kosasih, (2010:73) tentang manfaat metode latihan berjenjang adalah untuk memperoleh kecakapan motoris, seperti menulis, melafalkan huruf, membuat dan menggunakan alat-alat, untuk memperoleh kecakapan mental, seperti perkalian, penjumlahan, pengurangan, pembagian, tanda-tanda/simbol-simbol, untuk membentuk kebiasaan dan menambah ketepatan dan kecepatan pelaksanaan". Simpulannya juga demikian. "Dari keterangan di atas, dapat ditarik kesimpulan bahwa tujuan dan manfaat metode Latihan Berjenjang adalah untuk melatih kecakapan motoris dan mental untuk memperkuat asosiasi yang dibuat.

Kalimat-kalimat berikut adalah contoh kegiatan plagiasi. "mental murid untuk menerima ....", "Hal yang harus dilakukan seperti: Memberikan penjelasan seperlunya tentang suatu kegiatan yang perlu dilaksanakan dengan menggunakan metode latihan berjenjang. Tujuannya adalah untuk memberikan gambaran perbuatan yang perlu dicapai dengan menggunakan metode sehingga murid memahaminya penggambaran itu disertai contoh-contoh perbuatan yang perlu dilaksanakan. Apabila keterangan-keterangan yang diberikan telah cukup perlu kiranya diberi latihan pendahuluan sebagai persiapan untuk melaksanakan latihan yang sesungguhnya. Guru memberikan contoh yang benar dalam bentuk gerak kemudian murid menirukan. Kegiatan Inti Murid melaksanakan latihan yang mempunyai kesukaran-kesukaran yang masih dapat diatasi oleh murid. Latihan ini diulang-ulang sampai murid benar-benar telah dapat melaksanakan gerak maupun bacaan yang menjadi materi pembelajaran dengan metode latihan berjenjang.

Mengadakan kontrol atau mengadakan koreksi terhadap latihan, memeriksa kesalahan-kesalahan pada waktu melaksanakan tugas latihan. Bila ditemukan kesalahan, langsung dianalisa, dibicarakan, seperlunya diperbaiki kemudian dilatih lagi. Penutup Melaksanakan perbaikan terhadap kesalahan-kesalahan yang dilakasanakan oleh murid. Memperbaiki latihan penenang Sadirman (2006:23). Teori kekurangan dan kelebihan metode latihan berjenjang terindikasi plagiat. Kalimat "Menghambat bakat dan inisiatif (tindakan) siswa karena siswa lebih banyak dibawa kepada penyesuaian dan diarahkan kepada jauh dari pengertian. Menimbulkan penyesuaian secara statis kepada lingkungan, dimana peserta didik menyelesaikan tugas secara statis sesuai dengan apa yang diinginkan oleh guru. Membentuk kebiasaan yang kaku, artinya seolah-olah siswa malakukan sesuatu secara mekanis, dalam memberikan stimulus siswa bertindak secara otomatis. Menimbulkan verbalisme, terutama pengajaran yang bersifat menghafal. Dimana siswa dilatih untuk dapat menguasai bahan pelajaran secara hafalan dan secara otomatis mengingatkannya bila ada pertanyaan yang berkenaan dengan hafalan tersebut tanpa suatu proses berpikir secara logis Kelebihan Metode Latihan Berjenjang Dapat memperoleh kecakapan motoris, seperti menulis, melafalkan huruf, membuat dan menggunakan alat-alat Dapat memperoleh kecakapan mental, seperti perkalian, penjumlahan, pengurangan, pembagian, tanda-tanda/simbol-simbol. Dapat membentuk kebiasaan, menambah ketepatan dan kecepatan pelaksanaan E.Kosasih (2010:73). Uraian kerangka berpikir juga sebagian diambil dari tulisan orang lain. Kalimat "kurangnya minat siswa dalam .... isi bacaan dengan membaca cepat $250 \mathrm{KPM}$.... siswa terhadap mata pelajaran bahasa Indonesia masih kurang.... untuk memperoleh suatu ketangkasan atau keterampilan tentang sesuatu yang dipelajari dengan malakukannya secara praktis, (Pasaribu 2001:112).

Bab III Metode Penelitian

Pada bagian ini diuraikan beberapa hal yang terindikasi plagiat. Kalimat judul bab "BAB III METODE PENELITIAN", pendapat Aqib (2006:33) "Rancangan penelitian diartikan sebagai strategi pengaturan latar penelitian agar peneliti memperoleh data yang valid sesuai dengan karakteristik variabel dan tujuan penelitian" terindikasi diambil dari tulisan orang lain", "Penelitian ini merupakan penelitian tindakan kelas (PTK) .... yang diteliti dalam penelitian tindakan kelas adalah masalah-masalah yang muncul pada pembelajara di kelas. Penelitian tindakan kelas bertujuan untuk memperbaiki dan meningkatkan praktik pembelajaran di kelas secara berkesinambungan (Aqib 2006:18).

Subjek dan Objek Penelitian juga diambil dari tulisan orang lain dengan mengedit sebagian. Kalimat "Subjek penelitian ini adalah siswa kelas ... SMP Negeri 3 Lolomatua .... Objek dalam penelitian ini adalah membaca cepat 250 KPM ....". Lokasi Penelitian Pada penelitian yaitu "SMP Negeri 3 Lolomatua .... alasan peneliti memilih lokasi ....". Waktu dan Lamanya Penelitian Sesuai yang direncanakan oleh peneliti, bahwa penelitian ini "dilaksanakan pada bulan Mei sampai" ... kali pertemuan dengan alokasi waktu ... mata pelajaran bahasa Indonesia di SMP Negeri 3...." Prosedur pelaksanaan Penelitian juga sebagian kalimat dikutip dari tulisan orang lain. Kalimat "... data pada penelitian ini ...membaca cepat 250 KPM. ...membaca cepat 250 KPM ... kemampuan siswa membaca cepat 250 KPM. 
Materi pelajaran yang diberikan di kelas VIII-A SMP Negeri 3 Lolomatua adalah membaca cepat 250 KPM. Tindakan yang meliputi proses kegiatan belajar mengajar membaca cepat 250 KPM ...." "membaca cepat 250 KPM. Refleksi yang meliputi kegiatan analisis hasil pembelajaran dan ... dalam upaya meningkatkan kemampuan siswa membaca cepat dengan menggunakan metode Latihan Berjenjang....". "Tindakan pada Siklus I Pada siklus I, peneliti .... Pertemuan pertama (I) Perencanaan Pada tahap perencanaan siklus I, peneliti mempersipkan perangkat pembelajaran membaca cepat dengan langkah-langkah sebagai berikut: Peneliti menyiapkan perangkat pembelajaran yang....", "Bekerjasama dengan guru mata pelajaran.... Tindakan yang dilakukan dalam.... Guru memberikan materi pelajaran yang akan ... Guru memberikan kesempatan kepada siswa untuk bertanya". "Pada tahap observasi ..., proses pembelajaran membaca cepat ... siswa selama proses pembelajaran.... Setelah melakukan kegiatan pembelajaran pada pertemuan pertama Pertemuan kedua (II) Pada tahap ini, peneliti... Tindakan yang dilakukan oleh ... mental murid untuk menerima .... Memberikan penjelasan seperlunya tentang suatu kegiatan yang perlu dilaksanakan dengan menggunakan metode Latihan Berjenjang". Tujuannya adalah untuk memberikan gambaran perbuatan yang perlu dicapai dengan menggunakan $\ldots$ penggambaran itu disertai contoh-contoh perbuatan yang perlu dilaksanakan. Apabila keterangan-keterangan yang diberikan telah cukup perlu kiranya diberi latihan pendahuluan sebagai persiapan untuk melaksanakan latihan yang sesungguhnya. Guru memberikan contoh yang benar kemudian murid menirukan Kegiatan Inti Murid melaksanakan latihan yang mempunyai kesukaran-kesukaran yang masih dapat diatasi oleh murid. Latihan ini diulang-ulang sampai murid benar-benar telah dapat melaksanakan Mengadakan kontrol atau mengadakan koreksi terhadap latihan, memeriksa kesalahan-kesalahan pada waktu melaksanakan tugas latihan. Bila ditemukan kesalahan, langsung dianalisis, dibicarakan, seperlunya diperbaiki kemudian dilatih lagi. Penutup Melaksanakan perbaikan tehadap kesalahan-kesalahan yang dilakasankan oleh murid. Memperbaiki latihan penenang (Sadirman 2006:23). Pada tahap observasi,...", "pada tahap refleksi ada beberapa kalimat yang terindikasi plagiat, "Pada tahap ini, peneliti ... yang disampaikan oleh guru". "Jika pada siklus I ... di SMP Negeri 3 .... "Prosedur Tindakan pada Siklus II .... refleksi pada siklus I .... "Perencanaan Pada tahap perencanaan ... I. Pada siklus II ini .... Adapun rencana tindakan yang akan dilakukan ... diupayakan dapat memperbaiki masalah atau kekurangan-kekurangan pada siklus I. Tindakan yang dilakukan pada siklus II berbeda dengan tindakan pada siklus I. sebelum siswa .... Peneliti menjelaskan terlebih dahulu kesalahan-kesalahan hasil tes siswa pada siklus I. Peneliti menanyakan kesulitan yang dihadapi siswa dalam .... ".

"kegiatan pembelajaran pada siklus II .... Tindakan yang dilakukan oleh ... mental murid untuk menerima....". "Memberikan penjelasan seperlunya tentang suatu kegiatan yang perlu dilaksanakan dengan menggunakan metode Latihan Berjenjang. Tujuannya adalah untuk memberikan gambaran perbuatan yang perlu dicapai dengan menggunakan metode sehingga murid memahaminya penggambaran itu disertai contoh-contoh perbuatan yang perlu dilaksanakan. Apabila keterangan-keterangan yang diberikan telah cukup perlu kiranya diberi latihan pendahuluan sebagai persiapan untuk melaksanakan latihan yang sesungguhnya. Guru memberikan contoh yang benar kemudian murid menirukan. Kegiatan Inti Murid melaksanakan latihan yang mempunyai kesukaran-kesukaran yang masih dapat diatasi oleh murid. Latihan ini diulang-ulang sampai murid benar-benar telah dapat melaksanakan Mengadakan kontrol atau mengadakan koreksi terhadap latihan, memeriksa kesalahan-kesalahan pada waktu melaksanakan tugas latihan. Bila ditemukan kesalahan, langsung dianalisa, dibicarakan, seperlunya diperbaiki kemudian dilatih lagi. Penutup Melaksanakan perbaikan tehadap kesalahan-kesalahan yang dilakasankan oleh murid.". "Observasi Pada tahap observasi ... dalam proses pembelajaran dan ... kelemahan yang masih muncul ....". "Refleksi pada siklus II yaitu untuk merefleksi hasil evaluasi belajar siswa siklus I, ... kemajuan yang telah dicapai selama proses ... aktif dalam proses pembelajaran .... pembelajaran membaca cepat dengan menggunakan metode Latihan ....". Kekurangankekurangan pada siklus I telah....", “...Untuk mengumpulkan data dalam ... digunakan untuk mengetahui tingkat kemampuan siswa dalam membaca cepat. ... sejauh mana penerapan metode ... hasil belajar siswa dalam membaca cepat". "...unsur-unsurnya maupun besarnya bobot masing-masing unsur". "...Mengukur kecepatan membaca untuk diri sendiri dan...", "Adapun lembar observasi yang digunakan dalam penelitian ini yaitu: ... aktif dalam proses pembelajaran. Lembar observasi ini digunakan untuk mengumpulkan data ... yang dilakukan oleh guru ....".

Pada bagian teknik analisis data, terdapat kutipan yang terindikasi plagiat. Kalimat "Data yang digunakan dalam penelitian ini adalah ....". "... digunakan untuk mengetahui tingkat kemampuan siswa dalam membaca cepat...", "...dalam penelitian ini ada dua yaitu analisis data kuantitatif dan .... Teknik analisis data kuantitatif ....".

"Penskoran Skor diberi sesuai dengan kisi-kisi instrumen untuk memperoleh hasil tes kemampuan siswa dalam membaca cepat. Penjumlahan skor Setelah lembaran hasil membaca cepat siswa diberi skor sesuai dengan kisikisi instrumen, maka setiap skor dijumlahkan untuk mendapat skor akhir. Rokayah (2010:84) menyatakan cara menghitung nilai akhir dengan menggunakan rumus sebagai berikut".

Penulis skripsi juga menggunakan beberapa uraian rumus yang diambil sebagian dari tulisan orang lain. Jumlah nilai total "yang diperoleh dari hasil ... diorganisasikan sesuai pertanyaan peneliti". Pada bagian paparan data, penulis skripsi menggunakan beberapa kalimat dari orang lain, tetapi sudah diedit. Misalnya Penyimpulan, yaitu berdasarkan paparan "yang telah dibuat ditarik" ... kesimpulan dalam bentuk pertanyaan atau formula singkat". “... aktif dalam proses pembelajaran ...". 
Bab IV Temuan Penelitian dan Pembahasan

Pada bagian ini terdapat bagian-bagian kalimat yang terindikasi di-copy paste dari tulisan orang lain, seperti "Penelitian tindakan kelas ini ... di SMP Negeri 3 Lolomatua....". Subjek penelitian ini adalah “... SMP Negeri 3 Lolomatua ... yang berjumlah 36 orang, .... SMP Negeri 3 Lolomatua ... mata pelajaran Bahasa Indonesia...”. Paparan data juga demikian. Beberapa kalimat terindikasi plagiat. Misalnya, kalimat "peneliti berkolaborasi dengan guru mata pelajaran ... mengampu mata pelajaran bahasa Indonesia di kelas ....". Hasil Penelitian "Pembelajaran pada siklus I Pada siklus I ... sebanyak dua kali pertemuan ... Rencana Pelaksanaan Pembelajaran (RPP)". " ...mata pelajaran bahasa Indonesia“. "Pembelajaran pada siklus I pertemuan ... dilakukan mulai dari tahap .... Uraian setiap tahap pelaksanaan penelitian adalah sebagai berikut. Perencanaan Pada tahap perencanaan ini ... mempersiapkan segala sesuatu yang .... Menyusun Rencana Pelaksanaan Pembelajaran (RPP) ... peserta didik dan guru. "...pembelajaran membaca cepat 250 KPM dengan menggunakan metode pembelajaran Latihan Berjenjang dan alokasi waktu 2x40 menit....”.

Kegiatan Awal Guru/peneliti menyapa siswa Guru/peneliti "memperkenalkan diri kepada siswa” ... mengabsen siswa untuk mengetahui jumlah siswa yang hadir .... kalimat "Kegiatan Inti Eksplorasi", "Dalam kegiatan eksplorasi ....", “... membaca cepat Memberi kesempatan kepada siswa untuk menanyakan hal-hal yang belum ... sama dengan peserta didik ... didik lain mencatat waktu yang dicapai secara bergantian". "... waktu yang telah ditentukan dengan". Dalam kegiatan Konfirmasi, guru/peneliti: "Memberikan konfirmasi terhadap hasil eksplorasi dan elaborasi peserta didik melalui berbagai sumber. Memfasilitas peserta didik melakukan refleksi untuk memperoleh pengalaman belajar yang telah dilakukan. Dalam kegiatan Akhir, ...Melaksanakan perbaikan terhadap kesalahan-kesalahan yang ...". "... rencana pembelajaran pada pertemuan berikutnya". "Observasi Pada tahap observasi, ... seluruh aktivitas dan kreatifitas siswa selama proses pembelajaran berlangsung. Pada tahap refleksi, kegiatan yang akan dilaksanakan "meliputi kegiatan analisis hasil" ... materi pembelajaran yang akan diajarkan". Memotifasi siswa agar lebih aktif dalam mengikuti proses pembelajaran....". "Pertemuan Kedua Pelaksanaan pembelajaran pada siklus I pertemuan ....". "Uraian setiap tahap pelaksanaan penelitian adalah sebagai berikut. Perencanaan Pada tahap perencanaan ini peneliti mempersiapkan segala sesuatu yang ... Menyusun Rencana Pelaksanaan Pembelajaran (RPP) ... peserta didik dan guru ... pembelajaran membaca cepat 250 KPM dengan menggunakan metode pembelajaran Latihan Berjenjang dan alokasi waktu 2x40 menit ....". “...mengabsen siswa untuk mengetahui ....". “....Kegiatan Inti Eksplorasi Dalam kegiatan eksplorasi ...". "...pembelajaran membaca cepat dengan menggunakan metode ... sama dengan peserta didik ... didik lain mencatat waktu yang dicapai secara bergantian". "...waktu yang telah ditentukan dengan ... teks yang telah dibaca".

Dalam kegiatan Elaborasi, guru/peneliti: "Memberikan konfirmasi terhadap hasil eksplorasi dan elaborasi peserta didik melalui berbagai sumber. Memfasilitas peserta didik melakukan refleksi untuk memperoleh pengalaman belajar yang telah dilakukan. Kegiatan Akhir Dalam kegiatan penutup, ... Melaksanakan perbaikan terhadap kesalahan-kesalahan yang ....". "Menyampaikan rencana pembelajaran pada pertemuan berikutnya". "Pada tahap observasi, ... seluruh aktivitas dan kreatifitas siswa selama proses pembelajaran berlangsung. "...siswa yang tidak aktif dalam

... meliputi kegiatan analisis hasil...".

Selanjutnya, Hasil "perolehan nilai siswa pada siklus I" ... Tabel 4.1 Hasil Tes Kemampuan Siswa Membaca Cepat ... siswa dalam membaca cepat 250 KPM pada siklus I ... menggunakan rumus sebagai berikut". "...tabel di atas diperoleh ... membaca cepat 250 KPM....".

Nilai rata-rata "siswa dalam membaca cepat adalah" .... yang tidak mencapai KKM ....".

"tingkat kemampuan siswa dalam membaca cepat ... di bawah ini. Tabel ... Kemampuan Siswa Membaca Cepat 250 KPM....". "Berdasarkan tabel di atas, ... tingkat kemampuan siswa dalam membaca cepat 250 KPM ....". Hasil Tes "Kemampuan Siswa Membaca Cepat 250 KPM". “... siswa yang memperoleh nilai ... siswa yang memperoleh nilai ... siswa yang memperoleh nilai ... siswa yang memperoleh nilai ... di bawah ini. Tabel 4.3.". "Persentase Ketuntasan Siswa dalam "Pembelajaran Membaca Cepat 250 KPM dengan Menggunakan Metode ... belajar pada siklus I". "... Siswa dalam Membaca Cepat 250 KPM pada Siklus I". "...pembelajaran pada siklus II. Pembelajaran pada Siklus II". “... refleksi pada siklus I ... tindakan pada siklus I ... pembelajaran pada siklus II".

Pembelajaran pada siklus ke II terdiri dari dua "kali pertemuan dengan alokasi waktu" Dalam pelaksanaan pembelajaran pada siklus ... Perencanaan Pada tahap perencanaan ... mempersiapkan segala sesuatu yang ... Menyusun Rencana Pelaksanaan Pembelajaran (RPP)....". Tindakan Pada tahap tindakan "ini peneliti melaksanakan kegiatan" sebagai berikut.

Ada beberapa kalimat yang terdeteksi sebagai bagian dari kegiatan plagiat pada paparan kegiatan guru di siklus kedua, yakni kalimat pada "mengabsen siswa untuk mengetahui... Kegiatan Inti Eksplorasi Dalam kegiatan eksplorasi, ... pembelajaran membaca cepat dengan menggunakan metode ... sama dengan peserta didik ... didik lain mencatat waktu yang dicapai secara bergantian. ... waktu yang telah ditentukan dengan. ...teks yang telah dibaca. ...Memberikan konfirmasi terhadap hasil eksplorasi dan elaborasi peserta didik melalui berbagai sumber. 
Memfasilitas peserta didik melakukan refleksi untuk memperoleh pengalaman belajar yang telah dilakukan. Kegiatan Akhir Dalam kegiatan akhir, ... Melaksanakan perbaikan terhadap kesalahan-kesalahan yang .... Menyampaikan rencana pembelajaran pada pertemuan berikutnya. ... Observasi Pada tahap observasi, ... seluruh aktivitas dan kreatifitas siswa selama proses belajar mengajar berlangsung. ... siswa yang tidak aktif dalam....".

Refleksi Proses evaluasi atau "refleksi pada siklus I ... diperbaiki pada siklus II....

Pertemuan kedua Pelaksanaan pembelajaran pada siklus II ... perencanaan, tindakan, observasi, dan refleksi. ... Pada tahap perencanaan ini ... mempersiapkan segala sesuatu yang .... Menyusun Rencana Pelaksanaan Pembelajaran (RPP) .... peserta didik dan guru ...dengan alokasi waktu 2x40 menit. ... mengabsen siswa untuk mengetahui ... memotivasi siswa agar lebih ... Kegiatan Inti Eksplorasi Dalam kegiatan eksplorasi ....”. “... sama dengan peserta didik ... didik lain mencatat waktu yang dicapai secara bergantian. ... waktu yang telah ditentukan dengan ... teks yang telah dibaca ... Memberikan konfirmasi terhadap hasil eksplorasi dan elaborasi peserta didik melalui berbagai sumber. Memfasilitas peserta didik melakukan refleksi untuk memperoleh pengalaman belajar yang telah dilakukan. Kegiatan Akhir Dalam kegiatan akhir, ... Bersama-sama dengan peserta didik ... Melakukan penilaian atau refleksi terhadap kegiatan yang sudah dilaksanakan secara .... Observasi Pada tahap observasi, guru mengamati seluruh aktifitas siswa selama kegiatan belajar mengajar berlangsung. .... selama proses pembelajaran siklus II ... siswa yang melakukan aktivitas dalam pembelajaran sudah berkurang".

Kegiatan "siswa dalam membaca cepat ..., ini dapat dilihat dari ... membaca cepat 250 KPM ... siswa yang kurang aktif....". Hasil "perolehan nilai siswa pada siklus II ini" ... di bawah ini. Tabel ... Membaca Cepat 250 Kpm ... menggunakan rumus sebagai berikut.

tabel di atas diperoleh ... kemampuan siswa membaca cepat 250 KPM ... kemampuan siswa membaca cepat 250 KPM ... siswa mampu membaca cepat 250 KPM ... tingkat kemampuan siswa dalam membaca cepat ... di bawah ini. Tabel....".

Persentase Tingkat Kemampuan Siswa Membaca Cepat 250 KPM ....". "Berdasarkan tabel di atas, ... peningkatan kemampuan membaca cepat 250 KPM ... Kemampuan Siswa Membaca Cepat 250 KPM pada Siklus II ... siswa yang memperoleh nilai ... siswa yang memperoleh nilai ... siswa yang memperoleh nilai $\quad .$. siswa yang memperoleh nilai ....".

Selanjutnya perbandingan antara persentase ketuntasan "siswa dalam membaca cepat 250 KPM ... di bawah ini. Tabel ... Pembelajaran Membaca Cepat 250 KPM pada Siklus II ... belajar pada siklus II ....". "Membaca Cepat 250 KPM pada Siklus II ... siswa selama proses pembelajaran membaca cepat dengan menggunakan metode..., dapat dilihat pada tabel di bawah ini: Tabel 4.7 Peningkatan Kemampuan Siswa Membaca Cepat 250 KPM pada Siklus I dan II...".

Berdasarkan tabel di atas, ... siswa pada siklus I, dan pada siklus II ... kemampuan siswa dalam membaca cepat 250 KPM. Peningkatan Kemampuan Siswa Membaca Cepat 250 KPM pada Siklus I dan Siklus II ... kemampuan siswa membaca cepat 250 KPM dengan menggunakan metode ...”. “... kemampuan siswa membaca cepat 250 KPM dengan menggunakan metode ... siswa pada siklus I ... banyak siswa yang tidak

... jumlah siswa yang diamati sebanyak 36 orang. ... aktif dalam proses pembelajaran ... di bawah ini. Tabel ...". Hasil Observasi "Siswa pada Siklus I ... pada siklus II ini....".

“... jumlah siswa yang diamati sebanyak 36 orang ... aktif dalam proses pembelajaran dapat terlihat pada tabel di bawah ini. Tabel ....". kalimat “... mengikuti pembelajaran membaca cepat 250 KPM ... Observasi Siswa Siklus I dan Siklus II ... dilakukan selama proses pembelajaran ... pembelajaran dengan menggunakan metode Latihan ... membaca cepat 250 KPM....". "Perbandingan Hasil Observasi Guru ... pada Siklus I dan Siklus II".

Kalimat yang membahas langkah-langkah pelaksanaan penelitian pada siklus II juga terdapat indikasi copy paste. Kalimat "...terlebih dahulu telah dibekali dengan pengetahuan secara teori kemudian dengan tetap dibimbing oleh guru, siswa disuruh ... sehingga menjadi mahir dan terampil (David dalam Ramlan, 1993:91). Setelah peneliti menerapkan metode pembelajaran

Beberapa kalimat pada hasil penelitian juga terindikasi plagiat. Misalnya,

Kalimat "kesulitan dalam memahami materi ... perlu dilanjutkan pada siklus....".

Simpulan hasil observasi juga terindikasi plagiat, yakni pada kalimat "pembelajaran membaca cepat 250 KPM ... pembelajaran membaca cepat $250 \mathrm{KPM}$... Hal ini dapat dilihat ... berdasarkan data yang diperoleh ... yang dilakukan pada siklus II ... kemampuan siswa membaca cepat 250 KPM ... Berdasarkan uraian di atas, maka dapat disimpulkan bahwa metode pembelajaran ... meningkatkan kemampuan siswa dalam membaca cepat 250 KPM. Guru memberikan kesempatan kepada siswa untuk membaca ... Guru memberikan bimbingan seperlunya apabila ada siswa yang mengalami kesulitan atau hambatan dalam membaca cepat dengan menggali pengetahuan atau informasi yang telah dimiliki sebelumnya sehingga masalah dapat diselesaikan. Pembahasan juga memiliki beberapa kalimat yang tidak jelas sumbernya. Misalnya, "yang digunakan dalam penelitian ini adalah metode ... untuk memperoleh suatu ketangkasan atau keterampilan tentang sesuatu yang dipelajari anak dengan melakukannya secara praktis....".

Dalam pelaksanaannya metode pembelajaran Latihan Berjenjang "siswa terlebih dahulu telah dibekali dengan pengetahuan secara teori kemudian dengan tetap dibimbing oleh guru siswa ... sehingga menjadi mahir dan terampil ... meningkatkan keterampilan membaca cepat 250 KPM ... SMP Negeri 3 Lolomatua ... Latihan Berjenjang sehingga menjadikan siswa mampu membaca cepat. Nilai rata-rata yang diperoleh dari tes kemampuan siswa membaca cepat $250 \mathrm{KPM}$... pembelajaran Latihan Berjenjang dan...." 
Bab V Penutup

Kalimat yang terdapat pada bagian ini juga terindikasi plagiat. Kalimat “... maka dapat disimpulkan bahwa kemampuan siswa membaca cepat 250 KPM dengan menggunakan metode ... SMP Negeri 3 Lolomatua ... terdiri dari dua siklus ... masing-masing siklus terdiri dari ... Hal ini terlihat dari meningkatnya kemampuan siswa membaca cepat ....”. “...belajar siswa dalam membaca cepat 250 KPM ... dan pada siklus II nilai rata-rata ...pembelajaran pada siklus I ... dan pada siklus II ... dan pada siklus II ...". "...kemampuan siswa membaca cepat 250 KPM ... Berdasarkan uraian di atas, maka dapat disimpulkan bahwa metode pembelajaran ... meningkatkan kemampuan siswa dalam membaca cepat 250 KPM. Terdapat beberapa kalimat pada subjudul saran yang diberikan oleh peneliti berdasarkan temuan penelitian adalah, diantaranya, yaitu "mata pelajaran bahasa Indonesia ... memilih metode pembelajaran yang sesuai dengan ... sehingga proses pembelajaran lebih. ... aktif dalam proses pembelajaran di kelas dan proses pembelajaran di kelas".

6. $\quad$ Berkat Daya Laia

Similarity Found: $21 \%$

Date: Rabu, Juli 03, 2019, Statistics: 2460 words Plagiarized / 11537 Total words

Bab I Pendahuluan

Pada bagian latar belakang masalah, penulis skripsi mengutip beberapa pendapat ahli dan pernyataan yang sumbernya belum jelas. Misalnya, kalimat “... baik secara lisan maupun. ...mata pelajaran bahasa Indonesia, ... keterampilan menyimak, keterampilan berbicara, keterampilan .... Salah satu keterampilan berbahasa yang diajarkan. Pengertian menulis juga dikutip dari pendapat Akhadiah (1986:11) yaitu "merupakan suatu keterampilan menuangkan... Hal ini sesuai dengan ... bahwa menulis merupakan suatu ... menguasai topik dan permasalahan.... Keterampilan menulis bukan sekedar menulis simbol-simbol ... sehingga berbentuk kata, dan kata disusun menjadi kalimat menurut aturan tertentu, akan tetapi ... secara utuh, lengkap dan jelas sehingga buah pikiran tersebut dapat dikomunikasikan .... Pendapat Tarigan (1987:21) menyatakan bahwa "menulis adalah menurunkan atau melukiskan lambang-lambang grafik yang menggambarkan bahasa yang dapat dipahami seseorang sehingga orang lain dapat ... lambang-lambang grafik tersebut kalau mereka memahami bahasa dan .... yang diperoleh siswa belum mencapai ... oleh guru mata pelajaran yang....". .... menguasai komponen (1) grafologi, (2) struktur, (3) kosa...".

Hasil observasi juga diindikasikan sebagian di-copy dari tulisan orang lain. kalimat tersebut misalnya, "dipengaruhi oleh beberapa factor", ... Masalah tersebut dapat diatasi dengan...". pendapat Winarno (1980: 115116) juga di-copy dari tulisan orang lain. kalimat "... melibatkan siswa secara langsung....". Selanjutnya, pendapat Roestiyah (2001:85) tentang teknik objek langsung (direct object) adalah "cara mengajar yang dilaksanakan dengan mengajak siswa ke suatu tempat atau ... tertentu di luar sekolah untuk mempelajari atau menyelidiki sesuatu seperti meninjau ... Siswa Kelas X SMA Negeri 1. Kalimat batasan masalah juga diambil sebagian dari hasil kerja orang lain, seperti kalimat “...dapat meningkatkan keterampilan menulis...." Rumusan masalah juga diambil dari tulisan orang lain. seperti kalimat "Masalah Berdasarkan latar belakang ... objek langsung dapat meningkatkan keterampilan menulis... tujuan penelitian yang hendak dicapai adalah sebagai berikut".

Objek langsung dapat meningkatkan keterampilan menulis. Pada bagian ini, ada beberapa kalimat yang di-copy, misalnya "... manfaat penelitian ini adalah sebagai berikut"," ...aktif dalam proses pembelajaran untuk meningkatkan kemampuan menulis ... sehingga orang lain dapat... yang bertujuan untuk meyakinkan ... seseorang baik pembaca atau juga pendengar agar melakukan sesuatu ... melibatkan siswa secara langsung....". Bab II Kajian Pustaka

Pada bagian ini penulis menulis beberapa konsep dasar menulis, seperti pengertian menulis tetapi terindikasi plagiat. Kalimat "Menulis merupakan suatu keterampilan berbahasa yang dipergunakan untuk berkomunikasi secara tidak langsung dan tidak tatap muka dengan orang lain ... merupakan kegiatan yang produktif dan ekspresif. Dalam kegiatan menulis ini, penulis harus terampil memanfaatkan grafologi, struktur kata, dan kosa kata. Penulis juga mengutip pendapat Tarigan (1986:3-4) tentang keterampilan menulis. Selanjutnya, pendapat Nurgiyantoro (2001:298), Sujanto (1988:56), Lado dalam Ahmadi (1997:143), Akhadiah (1997:3), Marwoto (2002:12) tentang pengertian menulis. Simpulan tentang menulis juga terindikasi diambil dari hasil tulisan orang lain. beberapa kalimat yang tidak jelas sumbernya, misalnya "Tulisan merupakan sebuah sistem komunikasi antar manusia yang menggunakan simbol atau lambang bahasa yang sudah disepakati pemakaiannya. Komunikasi tertulis terdapat empat unsur yangterlibat di dalamnya, yaitu (1) penulis, (2) pesan atau isi tulisan, (3) saluran atau media tulisan, (4) pembaca sebagai penerima pesan".

Teori tentang tujuan menulis juga diambil oleh penulis pada tulisan orang lain. misalnya pendapat Hartig dalam Tarigan, 1986:24-25), Tarigan (1994:24), Sujanto (1988:68), Semi (1990:19), tentang tujuan menulis juga diambil. Simpulan juga diindikasikan plagiat. Kalimat “... di atas, dapat disimpulkan bahwa tujuan menulis adalah untuk ....". Teori-teori lain misalnya, manfaat menulis, prinsip menulis, proses menulis dikutip dari pendapat ahli, misalnya Mawabah (2011:66), tetapi terkesan plagiat karena terindikasi bahwa kutipan tidak diambil dari sumber asli. Kesimpulan yang dibuat juga diambil dari sumber yang tidak jelas.

Teori konsep dasar paragraf persuasif dibuat dengan mengutip pendapat ahli. Misalnya, pendapat Suparno (2007:5.47) dan Keraf (2007:118). Teori tujuan paragraf persuasi juga terindikasi plagiat. Kalimat "tujuan terakhir adalah agar pembaca atau pendengar melakukan sesuatu ... dapat dimasukkan pula dalam cara-cara untuk mengambil keputusan. Pendapat ahli juga diambil penulis skripsi, yakni pendapat Artati (2011:35) dan Keraf (1999:14) tentang paragraf persuasif. Pendapat Keraf (2007:118) tentang pengertian paragraf persuasi juga dikutip seperti kalimat berikut, Langkah-langkah menulis paragraf persuasif dikutip dari Roestiyah (2001:133). 
Contoh paragraf persuasif juga diambil dari contoh yang sudah kian dibuat oleh Roestiyah (2001:85). Simpulan juga selalu diambil dari sumber lain.

Konsep langkah-langkah teknik objek langsung juga terindikasi plagiat karena belum jelas pendapat tersebut bersmber dari mana. Sama halnya dengan konsep kelebihan teknik objek langsung (direct object) yang dikemukakan Syaiful Bahri Djamarah, 2006:94). Kekurangan Teknik Objek Langsung juga dikutip dari pendapat Syaiful Bahri Djamarah (2006: 94), Syaiful Sagala (2006: 215)

Bab III Metode Penelitian

Pada bagian ini, ditemukan beberapa kutipan dan kalimat pernyataan yang tidak diambil dari sumber aslinya. Misalnya, kalimat “... dicapai, maka penelitian ini .... Penelitian tindakan kelas merupakan penelitian ... guru dapat mengorganisasikan kondisi praktek pembelajaran ..." pendapat Sukaryana (2006:9) dan Arikunto (2006:3) tentang PTK juga diambil dari tulisan orang lain. uraian objek penelitian, subjek penelitian, alasan peneliti memilih lokasi penelitian, waktu dan lamanya penelitian, prosedur penelitian, uraian tentang instrumen penelitian sebagian hasil plagiat. Teknik Analisis Data juga termasuk dalam kategori plagiat, termasuk uraian singkat penggunaan rumus,

BAB IV Temuan Penelitian dan Pembahasan

Pada bagian ini, terdapat kalimat yang tidak dapat dipertanggungjawabkan keasliannya. Misalnya, tahap pelaksanaan penelitian, yakni uraian tentang "perencanaan, tindakan, observasi, dan refleksi" terkesan banyak diambil dari sumber yang tidak jelas. Dekripsi pelaksanaan penelitian berupa aktivitas yang dilakukan guru dan peneliti terindikasi tidak murni hasil pekerjaan penulis skripsi.

BAB V PENUTUP

Ada beberapa kalimat yang berkategori tidak murni hasil tulisan penulis skripsi, misalnya "rumusan masalah dan tujuan penelitian ... proses pembelajaran Bahasa Indonesia di sekolah. ...langkah-langkah menulis paragraf persuasif ... bagi guru mata pelajaran bahasa Indonesia". Pada bagian saran terdapat kalimat "...aktif dalam proses pembelajaran di kelas sehingga proses pembelajaran yang terjadi di kelas tidak monoton.

\section{PENUTUP}

\section{Kesimpulan}

Setelah dilakukan analisis, permasalahan yang terdapat pada skripsi yang dijadikan sampel penelitian kurang lebih sama. Yang membedakannya adalah persentasenya. Misalnya skripsi a.n. Derisman Bawamenewi dengan Similarity Found: 33\%, skripsi Eldison dengan Similarity Found: 25\%, skripsi Ernimawati Gulo dengan Similarity Found: $21 \%$, skripsi Etika Halawa Similarity Found: 54\%, skripsi Gakhimi Wau Similarity Found: 27\%, skripsi Intan H. Laia Similarity Found: 23\%, skripsi Nur Kaidah Dachi Similarity Found: 30\%, skripsi Reminis Cere Hia Similarity Found: 43\%, skripsi Salua B. Gowasa Similarity Found: 20\%, skripsi Report Suci Hati Buulolo Similarity Found: 21\%, Sinjo Bu'ulolo Bab I-III Similarity Found: 60\% dan Bab 4-5 Similarity Found: 11\%, Wenihati Gaurifa Similarity Found Bab I: 7\%, Bab II: 80\%, Bab III: 14\%, Bab IV: 7\%, Bab V: 4\%, Yustina Novewati Bu'ulolo Bab IIII Similarity Found: 56\% dan Bab 4-5 Similarity Found: 14\%.

Permasalahan yang muncul juga hampir sama. Hal-hal yang sangat rentan terhadap aksi plagiat adalah sebagai berikut.

Pada Bab I:

- $\quad$ penulis memberikan pengertian atau definisi tanpa jelas sumbernya,

- $\quad$ mengutip pendapat ahli atau KBBI tetapi tidak diambil dari sumber asli, melainkan dikutip dari tulisan orang lain.

- $\quad$ beberapa permasalahan pada latar belakang masalah juga diambil dari sumber yang tidak jelas. Artinya bahwa penulis skripsi menyajikan beberapa permasalahan dalam skripsinya tetapi sebagian dari permasalahan tersebut tidak benar adanya.

- Judul skripsi juga diambil dari tulisan orang lain, tetapi sudah diedit, terutama lokasi dan tahun penelitian.

- Pada bagian rumusan masalah, tujuan penelitian, manfaat penelitian, dan definisi istilah

Pada Bab II Kajian Pustaka

- $\quad$ Teori yang digunakan oleh penulis skripsi juga sebagian diambil dari sumber yang tidak jelas, kutipan juga diambil dari pendapat ahli, tetapi tidak dari sumber asli, melainkan dari tulisan orang lain.

- Beberapa uraian penjelasan teori juga diambil sebagian dari sumber yang tidak jelas.

- $\quad$ Ada juga kutipan dari ahli tetapi tidak lengkap identitasnya: ada yang tidak ada tahun dan halaman, atau ada tahun tetapi tidak ada halaman.

- $\quad$ Teori juga sebagian diambil dari internet (blok pribadi) bukan dari jurnal atau artikel yang dapat dipercaya keakuratannya.

Pada Bab III Metodologi Penelitian

- Kutipan dari ahli juga diindikasikan plagiat karena tidak diambil dari sumber asli.

- $\quad$ Beberapa kalimat pada setiap subjudul di bab III juga terindikasi plagiat karena tidak terdapat sumber yang jelas.

Bab IV Temuan Penelitian dan Pembahasan

Ada beberapa kalimat yang terindikasi plagiat. Misalnya kalimat yang menguraikan pelaksanaan penelitian, kalimat yang digunakan untuk mendeskripsikan hasil penelitian. 
Vol. 6, SNo. 2 (2019)

Hal : $10-23$

Bab V Penutup

Ada sebagian kalimat yang terdeteksi tidak murni tulisan penyusun skripsi. Akan tetapi, sangat sedikit jumlahnya. Aksi plagiasi yang paling banyak jumlahnya adalah pada bab II.

\section{UCAPAN TERIMA KASIH}

Pada kesempatan ini penulis mengucapkan terima kasih yang sebesar-besarnya kepada Direktorat Riset dan Pengabdian Masyarakat, Direktorat Jenderal Penguatan Riset dan Pengembangan, Kementrian Riset, Teknologi, dan Pendidikan Tinggi yang telah menghibahkan dana penelitian kepada para penulis hingga proses penyelesaian.

\section{DAFTAR PUSTAKA}

[1] Ariani, Rachmatul Candra. 2011. Opini Mahasiswa Fakultas IImu Sosial dan IImu Politik Universitas Airlangga Terhadap Plagiarisme. (Online) Jurnal Sosial dan Politik. http://journal.unair.ac.id/filerPDF/JURNALCANDRA.docx. Diakses pada 30 April 2016.

[2] Arikunto, Suharsimi. 2006. Prosedur Penelitian Suatu Pendekatan Praktis.Jakarta: Rineka Cipta.

[3] Atmazaki. 2009. Kiat-kiat Mengarang dan Menyunting. Padang: UNP Press.

[4] Dalman, H. 2014. Keterampilan Menulis. Jakarta: Rajagrafindo Persada.

[5] Dalman, H. 2012. Menulis Karya IImiah. Jakarta: Rajagrafindo Persada.

[6] Djuharie, O. Setiawan. 2010. Pedoman Penulisan Skripsi, Tesis, Disertasi. Bandung: Yrama Widya.

[7] Dwiloka, Bambang dan Rati Riana. 2005. Teknik Menulis Karangan Ilmiah. Jakarta: Rineka Cipta.

[8] Gani, Erizal. 2011. Menulis Karya IImiah: Teori dan Terapan. Padang: UNP Press.

[9] Hs. Widjono. 2012. Bahasa Indonesia: Mata Kuliah Pengembangan Kepribadian di Perguruan Tinggi. Jakarta: Grasindo.

[10] Jauhari, Heri. 2008. Pedoman Penulisan Karya Ilmiah. Bandung: Pustaka Setia.

[11] Moleong, Lexy J. 2011. Metodologi Penelitian Kualitatif. Bandung: PT. Remaja Rosdakarya.

[12] Santoso, Urip. 2014. Kiat Menulis Artikel IImiah. Yogyakarta: Graha IImu.

[13] Soelistryo, Henry. 2011. Plagiarisme: Pelanggaran Hak Cipta dan Etika. Kanisius. Yogyakarta.

[14] Surakhmad, Winarno. 2004. Pengantar Penelitian Ilmiah Dasar, Metode dan Teknik. Bandung: Tarsito.

[15] Tim Peneliti FIP. 2012. Identifikasi Perilaku Plagiat pada Skripsi Mahasiswa Fakultas IImu Pendidikan (FIP) UNY. Artikel Penelitian. (Online):http://staff.uny.ac.id/sites/default/files/penelitian/Dr.BudiAstuti,M.Si./ Gidentifikasi bentuk plagiat pada skripsi mahasiswa.pdf. Diaksses pada 30 April 2016. 